\title{
John Calvin on the kingdom of God and eschatology
}

\author{
J.H. van Wyk \\ School for Ecclesiastic Sciences \\ Potchefstroom University for CHE \\ POTCHEFSTROOM \\ E-mail: amievw@intekom.co.za
}

\begin{abstract}
John Calvin on the kingdom of God and eschatology

In this article the author investigates Calvin's view on the kingdom of God and eschatology. The first question to be answered is: how does one know (anything about eschatology)? Calvin's answer is clear: only through the Word of God. The author continues to illustrate that for Calvin the expectation of the kingdom and the eschaton does not frustrate or annihilate the present, but stimulates and directs human activities. Attention is also paid to the realisation and fulfilment of the kingdom and the eschata, and the article ends with a critical evaluation of Calvin's views.
\end{abstract}

\section{Introduction}

The German theologian, Jürgen Moltmann (1996:XII), somewhere remarked that a theology of love characterised the Middle Ages, a theology of faith the Reformation, and a theology of hope the modern era. This remark suggests that the theme of Christian hope for the coming of the kingdom of God and the accompanying eschatology were underemphasised during the times of the Reformation. One can well ask whether eschatology had not been the stepchild of the Reformation during the sixteenth century. Was the reflection on Christian hope and the kingdom of God not totally overshadowed by the consciousness of Christian faith (cf. Wurth, 1959:58; Balke, 1992:213), specifically the justification through faith, called the "main hinge on which religion turns" (Inst. 3.11.1), yes "the sum of all piety" (Inst. 3.15.7)? Why would Christian faith be more fundamental than Christian hope? Did the struggle over the (true) church not overshadow, and even darken, the reflection over the kingdom of God? To put it more concretely: Why is the chapter 
on the eschatology in the Institutes ${ }^{1}$ of Calvin (3.25) so short and seemingly so one-sided? Why did Calvin not include much more of the extensive eschatological material found in his commentaries (and sermons) in his Institutes (cf. Balke, 1999:2)? Why did he not also write any commentary on the most eschatological book in the Bible, namely Revelation (Quistorp, 1941:3)? Why did he quote so little from Revelation (Wendel, 1978:285)? Why did Calvin write in such a controlled manner in his commentaries on Daniel and Matthew 24 (Fatio, 1989: 339)? Yes, how important was the eschatology during the Reformation of the sixteenth century, and for Calvin in particular? And what was understood under the concept eschatology?

In this article attention will be given to these - and also other - questions. A few introductory remarks will, however, first be levelled at how Calvin handles the concepts kingdom of God and eschatology.

- Eschatology does not merely pertain to the ending of time, but also to reality and the coming of the kingdom of God. Although one does not find an explicit and systematic treatment of the kingdom of God in Calvin's writings (Quistorp, 1941:1-3; cf. Asendorf, 1982:314-315), he nevertheless delegates an important role to the theme of the kingdom. In his Institutes (4.25) he focuses mostly on the final resurrection which is obviously attenuation - but the broader contours of the kingdom are more obvious in his commentaries, sermons, and Catechism.

- Calvin sets his doctrine on the kingdom of God against the identification of church and kingdom by the Catholic theology (cf. Hayes, 1989), the anticipation by the Anabaptism (the kingdom can be realised politically) and the Lutheran dualism with its two-domain doctrine (Wurth, 1959:59-67).

In his explanation of the second petition of the Our Father Calvin identifies the kingdom of God with the sovereignty of God. Calvin defines the kingdom as follows: God reigns where people have promised/ submitted themselves to his righteousness/sovereignty by striving for the heavenly life through self-denial and contempt for the world and their life on earth. The kingdom thus consists of two aspects, namely that God is to change our evil desires through his Spirit, and that God is to reform our senses so that we can obey his sovereignty (Inst. 3.20.42). The kingdom of God is where God reigns supreme through his Spirit (Catechism, 269 - see Calvin (1981)). The kingdom means forgiveness

1 References to Calvin's Institutes also refer to the Opera Selecta (Calvin, 1957). The Afrikaans translation of Simpson was also consulted (Calvyn, 1984-1992). 
of sins, salvation, life and, in full, all that we have gained in Christ (Inst. 3.3.19). The kingdom has already started, but the fullness of time is yet to come (Catechism, 271 - see Calvin (1981)). Calvin differentiates sharply between the spiritual kingdom of Christ and the civil government. He remarks that this differentiation boils down to Jewish vanity to search for and include the kingdom/realm of Christ in the elements of this world (Inst. 4.20.1). Although Calvin, on the one hand, sharply differentiates the spiritual kingdom/realm of Christ from the civil government, he, on the other hand, draws a relationship between the two. He finds no conflict between the two, since already on earth the kingdom of Christ establishes in us certain principles of the kingdom of heaven, which, in a certain way, already in this mortal and transitory life, initiate in us an immortal and incorruptible blessedness (Inst. 4.20.2). God thus establishes his kingdom in man by bending and reforming man's will through the Holy Spirit to seek for holiness and righteousness (Inst. 2.5.14,15).

Already at this stage of the explication Calvin's perception of the kingdom of God evokes certain pertinent questions, namely: Has the Platonic ontology not permeated his perception too much and does he not overly contrast an "ideal heavenly" kingdom to a "despised earthly" kingdom? Are church and kingdom not (sometimes) unduly (and overly) identified with one another (Inst. 4.1.13, 4.2.4, 4.5.9/17)?

\section{Eschatological knowledge}

Before giving more attention to the eschatology, attention needs to be given to an important preceding question. The question of what eschatological knowledge entails is of central importance when reflecting on the eschatology. Where and how do we gain knowledge of the coming of the kingdom of God, of the future and of future events? Thus viewed, the epistemological question precedes the ontological and futurological questions.

There are at least three possibilities for answering the epistemological question posed above, which we will also utilise for examining Calvin's viewpoint.

- The first possibility is that of speculative thought, presented by, for instance, the astrology. Calvin strongly denounces it as a source of knowledge for religious thought (Inst. 1.5.5). It is significant that Calvin, in contrast to, for instance, Melanchton, Osiander and Bullinger, writes in a much more restrained fashion on the apocalyptic (Fatio, 1989:339). Although Calvin accepted astronomy as a science, he rejected astrology - professing that the stars determine the course 
of life on earth - as diabolical superstition. Understandably, he differed radically from Melanchton, who held the opinion that planets and stars influence human life and determine the course of world history. Melanchton, for instance did not undertake a journey when the starstance did not favour him (Balke, 1992:210). Calvin adhered to the belief that God determined history and life.

- The second possibility is scientific thought. Notwithstanding the appreciation Calvin had for various sciences, he nevertheless found this form of logic inadequate for dealing with religious issues (Inst. 2.2.1427). All human knowledge, scientific knowledge included, is ever affected by sin and can therefore never understand whatever relates to the kingdom of God without the enlightening work of the Holy Spirit (Inst. 2.2.12).

- When dealing with the Great Future as a source of Christian hope, Calvin regards the knowledge of revelation as included in the Holy Scriptures as the one and only source of knowledge. Then, however, the boundaries of the Scriptural revelation should be revered. Man may not haughtily and inquisitively pry into secrets, which have not been made known.

Throughout his Institutes Calvin warns against an inquisitive questioning by man, especially concerning issues that are above the comprehension of man. We name a few examples.

In his treatment of the doctrine of the Trinity in Institutes 1.13 Calvin indicates the difficulty level of this dogma and adds "that men's minds, when they indulge their curiosity, enter into a labyrinth; and so let them yield themselves to be ruled by the heavenly oracles, even though they may fail to capture the height of the mystery" (Inst. 1.13.21).

Also in his doctrine on creation Calvin warns against unnecessary curiosity. He quotes Augustine's (Confessiones 11.12.14) tale of a pious old man who, when asked by an impetuous man what God did before the creation of the earth answered that He created hell for inquisitive people (Inst. 1.14.1)! We should not unnecessarily speculate on the nature and being of angels and give way to our curiosity, and then Calvin extols the heart (artery) of his theology:

Let us remember here, as in all religious doctrine, that we ought to hold to one rule of modesty and sobriety: not to speak, or guess, or even to seek to know, concerning obscure matters anything except what has been imparted to us by God's Word (Inst. 1.14.4). 
When dealing with the doctrine of the predestination (Inst. 3.21-24), and in particular with the everlasting perdition, the decretum horribile (Inst. 3.23.7), Calvin warns that "human curiosity renders the discussion of predestination, although somewhat difficult of itself, very confusing and even dangerous" (Inst. 3.21.1; vid. 3. 2.4).

Therefore, it is not surprising that in his eschatology Calvin continues his struggle against unnecessary curiosity and ingenuousness (Wendel, 1978:285; Kunz, 1980:37). Concerning the intermediary state and everlasting life, Calvin warns against speculation and levity (Inst. 3.25.6,10). In his commentary on Romans 8:21 he states:

God will restore to a perfect state the world, now fallen, together with mankind. But what that perfection will be, as to beasts as well as plants and metals, it is not meet nor right in us to inquire more curiously; for the chief effect of corruption is decay. Some subtle men, but hardly sober-minded, inquire whether all kinds of animals will be immortal; but if reins be given to speculation where will they at length lead us? Let us then be content with this simple doctrine, that such will be the constitution and the complete order of things, that nothing will be deformed or fading (Comm. Rom. 305).

Therefore, when Calvin unfolds his eschatology, he searches for revelation knowledge, for knowledge from the Word of God and not for human speculation or wisdom.

We would digress too far from our topic if we were to examine Calvin's doctrine on Scripture extensively (for a summary, compare Van Wyk, 1989:4-9; see in particular Inst. 1.6-9, 2.10-11, 3.2, 4.8). Therefore, suffice it to say that Calvin without doubt found Holy Scripture to be the source and norm of theology and also of eschatology. Whoever moves outside the realm of the Scriptural revelation when trying to answer questions on eschatology, inevitably falls into one or other form of speculation and wishful thinking.

In his Institutes (3.25.11) and also in a specific sermon (Fatio, 1989:349) Calvin ingeniously remarks that there are only a small handful of people from a great multitude who "care how they are to go to heaven, but all long to know beforehand what takes place there".

\section{Eschatological expectation}

\subsection{Work and expect (the intermediate time)}

Calvin perceives a specific relationship between eschatological expectation and earthly reality. In his Catechism (question 259), for instance, 
he remarks that the kingdom of God "can not come without our participating in it in one way or another". It is therefore clear that the eschatological expectation should not lead to a despising of the world (Kunz, 1980:35; Van Wyk, 1984:16-26). Although Calvin sometimes uses sharp expressions relating to our earthly existence, such as that we are to forsake (Inst. 2.15.5), despise, trample on (Inst. 3.9.1; 3.10.4) and deem valueless (Inst. 3.9.2) our present life, this contemptus should be understood in context and not in isolation: compared to the future life this life is but very relative (Inst. 3.9.4). "Of course it [earthy life] is never to be hated except in so far as it holds us subject to sin" (Inst. 3.9.4).

The remark has rightfully been made that "no one has emphasised more than Calvin our duty to serve God in daily life and in outward conduct" (Wallace, 1961:30). Calvin does not refrain from pertinently dealing with the present life and our usage of supports/aids (Inst. 3.10). All blessings in life are gifts from God. Man as a pilgrim (a recurrent theme) should guard against excessiveness and a lack of self-control, however, and direct him towards a proper use of the gifts (Inst. 3.10.1) by using only what he needs and what he can enjoy (clothes, wine, oil, flowers, gold, silver, ivory and marble) (Inst. 3.10.2).

Calvin specifically emphasised man's vocation (vocatio Dei) (Wurth, 1959:74-75). God not only calls man to be a citizen of his kingdom, but also to serve in society. Good works are the fruit of fulfilling one's vocation (Inst. 3.14.19), but man should in all circumstances and always, however, keep the calling of the Lord in mind (Inst. 3.10.6).

Expect while working, work while expecting - this is the motto of Calvin.

\subsection{Work and reflect (meditatio futurae vitae)}

It is clear to Calvin that man is both pilgrim and stranger (Inst. 3.7.3; 3.9.4-5; 3.10.1) and, as such, always on a life journey to his true Fatherland. The meditatio futurae vitae is therefore so necessary (Quistorp, 1941:33-45). It does not discredit the present life, but places it in its true context as a life-en-route. The eschatological expectation does not paralyse man and his work, but rather stimulates both. "Ethisches Leben ist eschatologisches Leben" (Kolfhaus, 1949:552). The theology of Calvin has room for neither asceticism nor quietism (Bremmer, 1943:86).

Eschatology and history influence one another reciprocally: history pushes forth to the end of the world, but the end of the world also pulls history onwards (Holwerda, 1976:112).

The alignment to the future life influences and determines the present life here and now; the present life is focused on the future life. Already in this 
world Christians live as citizens of heaven; earthly vocation and heavenly expectation go hand in hand for Calvin - as is also evident from his prayers (Balke, 1999:19-20).

\section{Eschatological realisation}

\subsection{The intermediate state (status intermedius)}

What happens to man - or his soul - after death?

By accepting the conscious existence of the soul after death - indeed, also the immortality of the soul (Inst. 1.15) - it is evident that Calvin's viewpoint must have been strongly influenced by the Platonic anthropology (cf. Kunz, 1980:32-33, 38-39; Van Wyk, 1993:18-20). Quistorp (1941:94, cf. 50-102) sees Calvin's doctrine on the intermediate state as the key problem of his eschatology (cf. Bremmer, 1943:92).

Calvin accepts that death is not the end of human existence and that the soul exists consciously in the presence of Christ (Inst. 1.15.2; cf 3.5.10; 3.9.4; 3.25.6) (Bremmer, 1943:70-76; Balke, 1999:6-8). He indeed emphasises the provisional and temporary character of the status intermedius since the full emphasis falls on the resurrectio carnis. The prayer for the dead is rejected (Inst. 3.5.10).

Calvin breaches the Platonic man-and-soul perception in at least five aspects:

- He has great appreciation for the human body.

- He emphasises the resurrection of the body.

- The soul does not exist from time immemorial, but is a creation of God (Inst. 1.15.5).

- The soul is not inherently immortal but receives its immortality from God.

- The soul does not incarnate, but exists in the presence of God after death (and, with the resurrection, is united with the body).

From the above-mentioned it is evident that Calvin also rejects the doctrine of the sleeping of the soul, as upheld by the Anabaptists compare, in this regard, his Psychopannychia (Zimmerli, 1932). He considers the sleeping of the soul as contrary to Philippians 1 . Also the intermediate process of purgatory, such as upheld in Roman Catholic theology, is rejected by Calvin. If sin is to be paid even after death, the redemption by atonement through Christ is adversely affected in its very essence, the cross of Christ is made meaningless, unbearable insult is 
directed at the mercy of God and our faith is destroyed - it is a fabrication of Satan's and blasphemy against Christ (Inst. 3.5.6-10) (cf. Quistorp, 1941:102-107).

\subsection{The end of time}

Also in his reflection on the events of the end of time, Calvin remains the sober theologian who adheres to Scriptural revelation. The signs are visible, but cannot be interpreted (cf. Bremmer, 1943:78).

With Augustine he rejects the expectation of a future thousand years of peace (chiliasm) as a "childish" idea (Inst. 3.25.5) (Quistorp, 1941:161166). The chiliasts restrict the reign of Christ to a thousand years, they secularise the kingdom of God, relegate it to being temporary and transient. The Scriptures, on the other hand, teach us that we are presently living in the intermediate time - between the coming and second coming - and that the cross and the resurrection of Christ are the great eschatological pivot of world history.

The antichrist is a figure from the end of time. Calvin sees him as rising from the church (Inst. 4.2.12) and taking form in the papacy and the accompanying falsification of the gospel (Inst. 4.2.12; 4.7.20-25; 4.9.4) (Balke, 1992:214-215; 1999:11-12). The antichrist also manifests as a kingdom (Bremmer, 1943:78), but, eventually, the antichrist and his kingdom will be defeated and destroyed by the kingdom and power of Christ.

For Calvin, eschatology converges mostly in the resurrection of the body - and Quistorp (1941:108-197) therefore also treats the eschatology of Calvin from this perspective (as Calvin himself does). It is in his belief in the resurrection of the body that Calvin most probably distances himself the most from the Platonic-idealistic anthropology. Calvin concedes that the resurrection is a "difficult subject", but indicates that the Scriptures simplify it by emphasising two issues, namely the resurrection of Christ and the omnipotence of God (Inst. 3.25.3-4,8). With reference to the resurrected body, Calvin accepts that it is the same body that arises (Inst. 3.25.7), with the same substantia, although the qualitas changes (Inst. 3.25.8; Catechism, 109). It is therefore wrong to say that the soul will be encased in another body (Inst. 3.25.6-7).

The chosen ones as well as those who are condemned will arise (Inst. $3.25 .9,12)$, the former in eternal bliss and the latter in eternal punishment (Inst. 3.25.5). Calvin thus rejects an apokatastasis pantoon; the sacrifice brought by Christ is sufficient pro toto mundo but effectively pro electis tantum (cf. Balke, 1999:17). The interpretation by Kunz (1980:39), that 
Calvin views the day of death and the last day as coincidental - a viewpoint currently also suggested by Durand (1993:17-20) - should, however, be questioned. This negates what Calvin teaches about the status intermedius and can even implicate the message of the resurrection. It is indeed true that Calvin writes that "there is not necessarily a time lapse between dying and the beginning of the second life" (Inst. 3.25.8), but then it pertains to an explication of 1 Corinthians 15:51 and of the transformation of the living during the last moment with the second coming of Christ. It does not allude to the state of (all) the deceased after death.

It is noteworthy that also as far as the second coming and the last judgment are concerned, Calvin encourages restraint and warns against curiosity and speculation (cf. Fatio, 1989: 349-350; Balke, 1999:14). Calvin expects the second coming to be visible. Then Christ will judge all (Inst. 2.16, 17; 4.17.12); a judgment that will be both merciful and damning (Quistorp, 1941:148-161).

The question that arises is: What will occur after the end events and where - and how - will the "everlasting life" carry into effect? With this, we have reached the final accords of Calvin's eschatology.

\section{Eschatological fulfilment}

\subsection{Personal fulfilment}

The pre-Reformation future expectation, and the Early Church in particular, placed a heavy accent on the visio Dei as the ultimate joy and final destination of the redeemed; salvation manifested in mysticism, contemplation and worship while in a state of mystical ecstasy (Balke, 1992:213-214). The tendency towards spiritualism is obvious. The emphasis on the visio Dei, for instance, forms a golden thread throughout the De Trinitate of Augustine.

Calvin, on the other hand, sees the aim of the resurrection as perpetual bliss (Inst. 3.25.10) and blessed immortality (Inst. 2.1.3, passim), to become a "participator in God's nature" (2 Pet. 1:4), because God will be glorified in his believers (Inst. 3.25.10).

What can be more exquisite and create more happiness than when the Lord gives Himself to be enjoyed by his children (frui Deo) and "somehow makes them to become one with Himself"?, Calvin asks with Augustine (Inst. 3.25.10). The personal eschatology focuses on God, to be one with Him and enjoy Him (Inst. 3.25.2). One day God will be all in all (1 Cor. 15:28), this is to say, God will be in all people and in all creatures, and God will be all in all believers (Comm. Cor. 33). In 
heaven, everybody will receive the everlasting life and a very special reward, although all will not share in equal glory (Inst. 3.25.10).

A question often posed in this context is related to the position of Christ in the Big Future after He has completed his intercessory work. Calvin remarks that the humanness of Christ will no longer serve as intercession, preventing us from a closer view on God (Comm. Cor. 33). This means that the intercessory role of Christ will end, but not his humanness (Kunz, 1980:40; cf Balke, 1999:17, in connection with the rare viewpoint of Van Ruler).

One wonders whether Calvin does not relate the end destination of man too much to "heaven" (cf. Inst. 2.10.1-23; 2.11; 3.25.1). In his commentary on Romans 8:19 he refers (Comm. Rom. 304) to "celestial glory" and on Romans 8:23 to "celestial inheritence" and "heavenly renovation" (Comm. Rom. 309). What becomes of the physical resurrection and the new earth in such an approach? Does Calvin not think in this respect too metaphysically and idealistically?

The question that arises - and we are going to examine this question more extensively - is what Calvin understands under the new heaven and the new earth.

\subsection{Cosmic fulfilment}

We have already indicated that not much attention is given to the new heaven and the new earth in Institutes 3.25 - although this aspect is not completely lacking (Inst. 3.25.11). In order to come more clearly to grips with Calvin's view on this theme, his commentaries in particular, which contain much more material on this theme than his Institutes, would have to be consulted (cf. Holwerda, 1976:137).

What does Calvin understand under the new heaven and the new earth? In his commentary on Isaiah 65:17 and 66:22 he notes (Comm. Isa. 398,437 ) that these texts refer to the restoration and renewal of the church after the Babylonian exile, but also to the renewal by Christ and eventually to the fullness of time.

From his commentaries on Romans 8:21 and 2 Peter 3:10, in particular, it is evident that Calvin accepts both a discontinuity (nova qualitas) and a continuity (manente substantia) between creation and recreation. The future glory of creation does not exist in a re-restoration of the original perpetuity, as Quistorp (1941:188) notes erroneously, but in a recreation and renewal where even the possibility of sin is excluded. What is coming, is a total renewal of the world, Calvin remarks when referring to Matthew 24:14 (Comm. Evg. 129). God restores man and world to a 
perfect state; nothing will be imperfect or transitory, says his commentary on Romans 8:21 (Comm. Rom. 305).

With reference to 2 Peter 3:10 Calvin comments (Comm. Cat. Ep. 421) that the elements of the world will be consumed but also renewed, while the substance will remain the same. In other words, while the quality will change, the substance will remain the same.

The cosmic contours are thus not lacking in Calvin's eschatology (Holwerda, 1976:134), although they are not strongly developed in the Institutes. Rightfully, the remark was made that Calvin's cosmic eschatology is closely linked to his Christology and ecclesiology (Quistorp, 1941: 190), and we could add: also to his Theology (doctrine of God) and anthropology (doctrine of man). With regard to his complete eschatology Quistorp (1941:191) concludes that, although Calvin mostly refers to heaven as the place of the glorified church, and sees salvation in the spiritual observation and enjoying of God, he, nevertheless, succeeds in warding off a mystical spiritualism (which sees the visible creation as worthless).

\section{Evaluation}

Finally, some evaluating comments are necessary.

\subsection{Positive criticism}

As positive criticism the following can be stated:

\section{- The Holy Scriptures as a key to eschatology}

Firstly, Calvin's connection to the Holy Scriptures as key to the understanding of eschatology should be appreciated (Quistorp, 1941:198). There is no other way to avoid speculation and acquire trustworthy knowledge about the future, than to refer to the Holy Scriptures. Even though it is true that scientific knowledge (astronomy, for instance) can contribute to a better understanding of the present and the future, we may never place our trust in or build our faith on it. Human knowledge remains shortsighted, restricted, and uncompleted. Only the Holy Scriptures carry the trustworthy message of faith, hope and love, of the cross and resurrection of Jesus Christ, of the renewing work of the Spirit of God, and of the new heaven and the new earth.

\section{- Rejection of quietism}

Secondly, Calvin's rejection of quietism is also valid. Eschatological expectation and a yearning for the future may not prevent us from fulfilling our earthly vocation, as the latter should not cloud our view to the Big 
Future. Calvin succeeded in sensibly relating the present and future, work and expectation to each other. In his theological considerations, he tried to find a way between secularism and asceticism, and between activism and quietism. He wanted to prevent both fanaticism and pietism.

\section{- Emphasis on physical resurrection}

Thirdly, Calvin's emphasis on the physical resurrection as an important for him, even a central - theme of the eschatology, should be appreciated in particular. In modernism and postmodernism exactly this theme, which is part of the ground-structure of the gospel, has come strongly in contention, particularly due to Bultmann's demythologisation programme. When the resurrection falls, then indeed the whole gospel falls, then we are to be pitied more than all men (1 Cor. 15:19). Cross and resurrection are the two hinges on which the door of the gospel swivels. His belief in the resurrection led Calvin to break with the Greek anthropology on this cardinal point.

\section{- The cosmic dimension in Calvin's eschatology}

Fourthly, the accent on the cosmic dimension in the eschatology of Calvin should be appreciated (different from Quistorp, 1941:3) - contrary to all forms of Gnosticism and Manicheism. Although underexposed, it is clear from Calvin's writings that he eventually foresees a new heaven and a new earth, and thus a new creation. In the end, God does not forsake the work of his hands.

\subsection{Negative criticism}

On the other hand, negative criticism can also be levelled against specific viewpoints of Calvin, such as the following.

\section{- Calvin's dualistic anthropology influenced by Platonism}

Firstly, Calvin's dualistic anthropology was without doubt strongly influenced by Platonism (Bremmer, 1943:93-94; Van Wyk, 1993:18, with references). He would have saved himself much criticism had he continuously replaced the concept soul with spirit (pneuma) and his thoughts would thereby also have acquired a stronger Scriptural character (Luke 23:46; Acts 7: 59; cf. Phil. 1:23). Thus, he would also have done more justice to the Biblical doctrine on the unity of man, created in the image of God. This would not have detracted anything from the fact of a (conscious) life after death.

\section{- Kingdom of God/heaven not developed as a central theme}

Secondly, although Calvin refers to the kingdom of God/heaven in many instances, it is neither used nor developed as a central theological theme 
- such as, for instance, occurred in the theological development of the twentieth century in general (cf. only Berkouwer, 1963:237-272; Willis, 1987; Snyder, 1991; Wentsel, 1991:534-611; Runia, 1997:105-135) and, in particular by Moltmann (1997:41-46). The kingdom of God was indeed the central theme in the preaching of Jesus Christ. Although Paul does not often use this concept explicitly in his letters, there is no doubt that he found it to be a defining theme (Acts 28:31). Calvin was also very tentative, as we have seen, to emphasise the earthly dimension of the kingdom. It must be conceded that the kingdom of God does not arise from the earth (John 18:36), but it is nevertheless true that the kingdom descends to the earth, enters into the earthly reality and here takes shape (Mt. 12:28). The kingdom enters the earthly reality by transforming, renewing, sanctifying, and purifying it (Wurth, 1959:62, 67, 68). We can say that the kingdom of God is no earthly kingdom, but indeed a worldly kingdom. In this broken reality it grows and permeates all life (Mt. 13:31-33).

\section{- The cosmic dimension is underexposed}

Thirdly, although it is not lacking, it must be said that, as has been mentioned already, the cosmic dimension (new earth) is underexposed, at least in the Institutes. One would go too far should one accuse Calvin of spiritualism (as does Quistorp, 1941:199; Balke, 1992:213; however, see Balke, 1999:15), but the question remains why Calvin gave so little attention to the new heaven and the new earth in the eschatological design of his main work. His thoughts were more "heavenly" than "earthly" and evoked the issue of Platonic influence (cf. Bremmer, 1943:87-92; Balke, 1999:18-19). That he also did not write a commentary on Revelation - and thus also not on Revelation 21:1, to which he nowhere refers in the Institutes - give impetus to critical questions.

Calvin might have been able to answer that Scriptures itself in many instances refer to the heavenly fatherland (cf. 2 Cor. 5:1-5; Heb 11:16; 1 Pet. 1:4), but the counter-question could have been that these references should be understood in their own context and in the context of the whole Bible and definitely not in the Greek-Platonic sense. In the Post-Reformation period the spiritualism and heaven-directedness received exceptional accent and much warped growth occurred (Quistorp, 1941:200), but in the Bible the last word on hope is about the new heaven and the new earth (cf. Van Wyk, 1998:311-331, with literature references).

To conclude: a "theology of love" is incomprehensible without a "theology of faith", as a "theology of love and faith" is incomprehensible without a "theology of hope". In his theological thoughts Calvin has succeeded 
admirably in keeping the dimensions of faith, love and hope together, and thus to relate the present and future, earth and heaven, here-present and hereafter logically to one another.

\section{Bibliography2}

ASENDORF, A. 1982. Eschatologie VII: Reformations- und Neuzeit. (In Krause, G. \& Müller, G., Hrsg Theologische Realenzyklopädie X. Berlyn : Walter de Gruyter. p. 310-315.)

BALKE, W. 1992. Omgang met de Reformatoren. Kampen : De Groot Goudriaan.

BALKE, W. 1999. Some characteristics of Calvin's eschatology. Address IRTI, June 1999. Doorn. Unpublished.

BERKOUWER, G.C. 1963. De wederkomst van Christus II. Kampen : Kok.

BREMMER, R.H. 1943. Enkele karakteristieke trekken van Calvijns theologie. Gereformeerd Theologisch Tijdschrift, 44:65-96, Jan.-Dec.

CALVIN, J. 1948a. Commentary on the book of the prophet Isaiah IV. Grand Rapids : Eerdmans. (Abbreviated as Comm. Isa.)

CALVIN, J. 1948b. Commentary of the epistle of Paul the apostle to the Romans. Grand Rapids : Eerdmans. (Abbreviated as Comm. Rom.)

CALVIN, J. 1948c. Commentary on the epistles of Paul the apostle to the Corinthians II. Grand Rapids : Eerdmans. (Abbreviated as Comm. Cor.)

CALVIN, J. 1948d. Commentaries on the Catholic epistles. Grand Rapids: Eerdmans. (Abbreviated as Comm. Cat. Ep.)

CALVIN, J. 1949. Commentary on the harmony of the evangelists, Matthew, Mark, and Luke. Grand Rapids : Eerdmans. (Abbreviated as Comm. Evg.)

CALVIN, Joannis. 1957. Opera Selecta (Barth, P. \& Niesel, G.) München: Kaiser.

CALVYN, J. 1984-1992. Institusie van die Christelike Godsdiens 1559 I-IV. Potchefstroom : CJBF. (Transl. H.W. Simpson.)

CALVYN SE KATEGISMUS. 1981. Potchefstroom : PTP. (Transl. H.W. Simpson; abbreviated as Catechism.)

Comm, Cat. Ep. see Calvin (1948d)

Comm. Cor. see Calvin (1948c)

Comm. Evg. see Calvin (1949)

Comm. Isa. see Calvin (1948a)

Comm. Rom. see Calvin (1948b)

DURAND, J.J.F. 1993. Theology and resurrection - metaphors and paradigms. Journal of Theology for Southern Africa, 82:3-20, March.

FATIO, O. 1989. Bemerkungen zu Zeit und Ewigkeit bei Calvin. (In Franke, T., Knapp, M. \& Schmid, J., Hrg. Creatio ex amore: Beiträge zu einer Theologie der Liebe: Festschrift für A. Ganoczy zum 60. Geburtstag. Würzburg : Echter Verlag. p. 338-351.)

2 KÖSTLIN, J. 1978. Ein Beitrag zur Eschatologie der Reformatoren: Theologischen Studiën und Kritiken. Gotha : Falk Verlag. (Unfortunately this source is not available in South Africa and could thus not be consulted.) 
HAYES, Z. 1989. Visions of a future: a study of Christian eschatology. Wilmington/ Delaware : Michael Glazier.

HOLWERDA, D.E. 1976. Eschatology and history: a look at Calvin's eschatological vision. (In Holwerda, D.E., ed. Exploring the heritage of John Calvin: essays in honor of John Bratt. Grand Rapids : Eerdmans. p. 110-139.)

KOLFHAUS, W. 1949. Vom christlichen Leben na Johannes Calvin. Neukirchen : Kreis Moers.

KUNZ, E. 1980. Protestantische Eschatologie von der Reformation bis zur Aufklärung. (In Schmaus, M. et al. Handbuch der Dogmengeschichte IV. Freiburg : Herder. p. 31-41.)

MOLTMANN, J. 1996. The coming of God: Christian eschatology. London : SCM.

MOLTMANN, J. 1997. Was heisst heute "evangelisch"? Von der Regfertigungslehre zur Reich-Gottes-Theologie. Evangelische Theologie, 57(1): 41-46.

QUISTORP, H. 1941. Die letzten Dinge im Zeugnis Calvins: Calvin's Eschatologie. Gütersloh : Bertelsmann.

RUNIA, K. 1997. Eschatology in the second half of the twentieth century. Calvin Theological Journal, 32(1):105-135, April.

SNYDER H.A. 1991. Models of the kingdom. Nashville : Abingdon.

VAN WYK, J.H. 1984. Calvyn oor die Christelike lewe. Pretoria : NG Kerkboekhandel.

VAN WYK, J.H. 1989. Die Woord is waardevol: 'n dogmatiese besinning oor die reformatoriese Skrifbeskouing. Potchefstroom : $\mathrm{PU}$ vir $\mathrm{CHO}$.

VAN WYK, J.H. 1993. Homo Dei: 'n prinsipiële besinning oor enkele mensbeskouings, waaronder dié van Calvyn. Supplementum I, In die Skriflig.

VAN WYK, J.H. 1998. Die nuwe hemel en die nuwe aarde: dogmatiese en etiese oorwegings oor 'n aspek van die eskatologie. In die Skriflig, 32(3):311-331.

WALLACE, R.S. 1961. Calvin's doctrine of the Christian life. Grand Rapids : Eerdmans.

WENDEL, F. 1978. Calvin: the origins and development of his religious thought. London : Collins.

WENTSEL, B. 1991. God en mens verzoend. Incarnatie, verzoening, koninkrijk van God. Dogmatiek 3b. Kampen : Kok.

WILLIS. W., ed. 1987. The kingdom of God in 20th-centruy interpretation. Peabody : Hendrickson.

WURTH, G.B. 1959. Calvijn en het koninkrijk God's. (In Vier redevoeringen over Calvijn. Kampen : Kok. p. 57-77.)

ZIMMERLI, W., Hrsg. 1932. Psychopannychia. Leipzig : Deichert.

\section{Key concepts:}

Calvin and the kingdom of God eschatology; Calvin's views meditatio futurae vitae new heaven and earth; Calvin's views status intermedius

\section{Kernbegrippe:}

Calvyn en die koninkryk van God eskatologie; Calvyn se siening meditatio futurae vitae nuwe hemel en aarde; Calvyn se siening status intermedius 


\title{
Response
}

\section{The kingdom of God and the theology of Calvin \\ Response to the paper by Prof. J.H. van Wyk}

\author{
P.F. Theron
}

Department of Systematic Theology \& Ecclesiology

University of Stellenbosch

STELLENBOSCH

E-mail: pft@maties.sun.ac.za

\begin{abstract}
The kingdom of God and the theology of Calvin. Response to the paper by Prof. J.H. van Wyk

It is argued that eschatology played a fundamental role in Calvin's theology. The significance of the concept "promise" puts paid to the accusation that Calvin lacks interest in eschatology. Predestination and resurrection are closely linked. The intimate relation between cross and resurrection is of prime importance in Calvin's thought. As in the theologia crucis of Luther, the glory of God nowhere shines more brightly than on the cross. Calvin's emphasis on the meditatio vitae futurae does not imply a flight from reality, but on the contrary, it means facing reality. He strongly rejects millenarian dreams, but that does not mean that his theology has no social impact and implications. Calvin calls us to a life of love, sacrifice, service and self-denial.
\end{abstract}

Despite the fact that Calvin never occupied the same position within the Reformed tradition that was accorded to Luther within Lutheranism, in the minds of many people "Reformed" and "Calvinism" are more or less synonymous. Although it is a moot point whether Calvin himself was a "Calvinist", it nevertheless can be said without fear of contradiction that he is the most famous of the founding fathers of Reformed theology. Accordingly Amie van Wyk does not deem it necessary to justify his choice to pay special attention to the theology of Calvin on this occasion. 
Does eschatology play a part in Calvin's theology?

As far as eschatology is concerned, some would say that the selection of Calvin is perhaps less obvious. Certain observers have blamed him for a lack of interest not merely in the concept of the kingdom of God, but also in the theme of eschatology as such. 1 In his well-known book on the Theology of Calvin, Wilhelm Niesel (1956) has no chapter that deals with Calvin's eschatology. Apparently Prof. Van Wyk also has a few misgivings with regard to the part eschatology plays in the theology of Calvin.

As can be expected Prof. Van Wyk has great appreciation for Calvin, especially the latter's aversion to speculation. That is most certainly a fundamental characteristic of Calvin's eschatology. In spite of the fact that Augustine is Calvin's favourite Father, he criticises the former for unfounded speculation on the relation between time and eternity (cf. Balke, 1999:3). The almost inordinate large proportion of Prof. Van Wyk's paper that is devoted to the preceding epistemological question, somehow implies that Calvin has not much to offer regarding the contents of eschatology.

I do agree with him that although the cosmic dimension is not lacking in Calvin's eschatology, it is possibly underexposed. On the other hand, that may be a case in point to demonstrate Calvin's loathing of autonomous speculation as is clearly indicated in his paper. Whether recent theology has done better on this score, is not certain. I love to think that my dog will partake in eschatological peace, but I do have a problem with mosquitoes. No doubt there are ingenious theologians who will be able to come up with a solution. It has been suggested that one could always think of a combination of a heaven for mosquitoes and a hell for man, but presumably Calvin would not approve of that kind of speculation. 2

To get a comprehensive picture of the role eschatology plays in the theology of Calvin, Van Wyk rightly points out that we should not confine ourselves merely to the Institutes, but also Calvin's commentaries, sermons and Catechism furnish valuable information. ${ }^{3}$ At the same time

1 Some characteristics of Calvin's eschatology. See Balke (1999:2): "Calvin has been frequently accused of lacking attention for eschatology".

2 According to Barth everything that has ever existed returns in eternity. That even includes every fly in the time of Hannibal because nothing was meaningless. See Dekker and Puchinger (1969:129). This hangs together with Barth's views on the relation between time and eternity. The contents of our hope is the "eternalising" of this ending life; cf. Berkouwer (1956:158).

3 As far as the commentaries are concerned, his Commentary on the Harmony of the Gospels as well as the Commentary on the Epistle to the Hebrews, merits special 
he reproves him for not doing justice to the kingdom of God, not merely as a concept - that would also apply to the apostle Paul - but as a central theological theme. In this regard I beg to differ.

It is significant that Calvin's very first theological treatise, Psychopannychia (which was published in 1534, republished in 1536 and 1542), is a work on eschatology. Tom Torrance (1956:90) maintains that from beginning to end "his exposition of Biblical eschatology characterised all his preaching and writing, while the prayers with which he regularly concluded his sermons and lectures indicate how profoundly eschatology had penetrated into the very heart of his faith" (Torrance, 1956:90). He then continues to demonstrate how eschatology permeates Calvin's entire teaching. As a matter of fact Prof. Van Wyk himself claims that Calvin's cosmic eschatology is closely linked not only to his Christology and ecclesiology, but also to his doctrine of God and doctrine of man. I would venture to say that eschatology is at the core of Calvin's theology.

\section{Calvin's pneumatology}

With good reason Calvin is often called the theologian of the Holy Spirit. In his Institutes eschatology is predominantly dealt with within his pneumatology (Book 3) which as such is an exposition of the meaning of our communion with Christ in whom the Kingdom of God is among us (Torrance, 1956:100). It is also crucial to note that in the final edition of the Institutes (1559) the doctrine of election is expounded within pneumatology, immediately preceding the chapter on the "last resurrection". It would be totally out of character for Calvin if we were to consider this organising of his subject matter to be merely fortuitous. Referring to this remarkable fact, Torrance calls election (pre-destination) and eschatology (post-destination) twin doctrines since Christ is simultaneously speculum predestinationis and speculum resurrectionis (Torrance, 1956:105). Calvin himself quotes Bernardus approvingly that through the work of the Spirit, calling and justifying freely by faith, "there is a kind of transition from eternal predestination to future glory." 4 Thus Torrance concludes that according to Calvin "eschatology is the doctrine

mentioning. To this we may add the striking De Scandalis and also Psycho-pannychia. Cf. Torrance (1956:100).

$4 \quad$ Inst. 3.13.4. Who can be saved? ask the disciples of Christ? He replies, With men it is impossible, but not with God. This is our whole confidence; this is our only consolation; this is the whole ground of our hope: but being assured of the possibility, what are we to say of his willingness? ... Here it is plain faith must come to our aid: here we must have the assistance of truth, in order that the secret purpose of the Father respecting us may be revealed by the Spirit, and the Spirit testifying may persuade our hearts that we are sons of God. But let him persuade by calling and justifying freely by faith: in these there is a kind of transition from eternal predestination to future glory. 
of the Spirit and all that the union with Christ involves" (Torrance, 1956: 101). This close connection between justification (respectively soteriology) and eschatology is of the utmost relevance when nowadays there is again a tendency to play kingdom of God and reconciliation off against each other. ${ }^{5}$

\section{"Faith" and "hope" should not be separated}

At the beginning of his paper, Van Wyk mentioned the view advocated by Moltmann that a theology of love characterised the Middle Ages, a theology of faith the Reformation, and a theology of hope the modern era. I would, however, like to submit that the importance of the concept "promise" in Calvin's theology puts paid to any such notion. Since the object of our faith is the promises of God, which are fulfilled in Christ's cross and resurrection, and by the Spirit imparted to us, it does not make sense to separate "faith" and "hope". As Calvin states in his commentary on 1 John 3:2: "Faith cannot stand otherwise than by looking to the coming of Christ". Or again in the Institutes (3.2.42) (the entire paragraph deals with the relation between faith and hope):

Wherever this living faith exits, it must have the hope of eternal life as its inseparable companion ... For if faith is (as has been said) a firm persuasion of the truth of God - a persuasion that it can never be false, never deceive, never be in vain, those who have received this assurance, must at the same time expect that God will perform his promises, which in their conviction are absolutely true; so that in one word hope is nothing more than the expectation of those things which faith previously believed to have been truly promised by God ... Faith believes that eternal life has been given to us; hope expects that it will one day be revealed.

Small wonder that Calvin calls the resurrection "the chief article of the faith" (Comm. on Matt. 28:7). ${ }^{6}$

Cf. Deurloo et al. (1998). It also takes the form of contrasting the proclamation of Jesus as a subjective genitive and the proclamation of Jesus as objective genitive. Cf. also Friedrich Beiszer (1993:91) on the eschatology of Calvin: "Die Sündenvergebung durch Christus, das künftige Leben, dem wir entgegengehen, und das jetzt in uns geschehende Gute, das in gewisser Weise die künftige Vollendung schon vorwegnimmt, dies alles sind nur verschiedene Seiten derselben eschatologischen Wirklichkeit."

6 Also Brunner (1925:148 ff.) draws attention to the close relationship between faith, hope and the promises. Cf. also Wendel (1990:285 ff.). Torrance differentiates between an "eschatology of faith" (Luther), an "eschatology of love" (Butzer), and an "eschatology of hope" (Calvin). I do, however, believe that he overestimates the difference between Luther and Calvin. He also characterises the difference between Luther and Calvin as "an eschatology of judgement going back to the early Latin Fathers" (Luther) and "an eschatology of resurrection going back to the early Greek Fathers” (Calvin, 1962:5). Cf. also Bakker (1964:75-78). 


\section{The relation between cross and resurrection}

Undoubtedly there does exist a fundamental difference between Calvin and many contemporary theologians, including Reformed theologians, as far as the nature of this hope is concerned. This hangs together with the intimate relation between cross and resurrection in Calvin's thought. In this respect there is no distinction between Calvin and Luther's well known crux sola est nostra theologia (cf. Forde, 1997; McGrath, 1985: chapter 5). Most certainly that does not entail a denial of the importance of the resurrection, but it does imply that cross and resurrection are more intimately related than is often realised.

I would hazard to say that in Calvin's view the resurrection takes the form of the cross in this dispensation. Neither faith and hope, nor cross and resurrection can be separated from each other. The one is the obverse of the other. As God is revealed sub contraria specie, the resurrection is revealed in the cross. In the entire creation God's glory is revealed, but in contrast to a theologia gloriae, God's glory nowhere shines more brightly than on the Cross. ${ }^{7}$ What is revealed for faith through the work of the Spirit, is concealed for the unbeliever. The glory of God's love takes the form of humility (respectively: humiliation). It is in this light that we should understand Calvin when he describes the Kingdom as "spiritual" and "heavenly" (Torrance, 1956:123).

In Christ the Kingdom of God has been fully realised, but he is totally opposed to any trace of "realised eschatology" with regard to the church, the sacraments, the ministry, or the principalities and powers of this world which in Calvin's view are destined to disappear. He rebukes Servetus for pretending that all the promises have been fulfilled as if there is no distinction between Christ and us, as if Paul was incorrect in saying that we are saved in hope (Inst. 2.9.3). In short: we already partake in Christ's resurrection, but during our pilgrimage in this world, it is revealed (respectively: concealed), as hy puts it in De Scandalis, in a life engaged in a perpetual warfare under the cross (in mundo peregrinatur, militet sub perpetua cruce). 8

7 Cf. Commentary on John 13:31 (after Judas had left to betray Jesus): "Now is the Son of Man glorified and God is glorified in him."

8 See Torrance (1956:125). Luther would say: jam factam ... nondum revelatam. Cf. Bakker (1964:51). 


\section{Life in this world}

This assessment of life in this world, with its concomitant emphasis on meditatio vitae futurae, is no flight from reality, but on the contrary, it is facing reality. Neither is it an indication of pessimism as Barth (cf. Retief, 1984) blames Calvin with respect to the relation between mortificatio and vivificatio (which corresponds with the relation between cross and resurrection). A life of love, sacrifice, service, self-denial and humility (cf. Inst. 3, 8: De crucis tolerantia), is as much a manifestation of the resurrection as of the cross. Under the conditions of this world, the new life of the resurrection takes the form of the cross. Therefore I cannot agree with Prof. Van Wyk when he intimates that Calvin's thoughts were more "heavenly" than "earthly". He is inclined to take the putative Platonic influence on Calvin much more seriously than I am willing to concede. ${ }^{9}$

Like Luther, Calvin strongly rejected millenarian dreams. Calvin himself most certainly cannot be blamed for the loss of transcendence that Benne perceives among his spiritual progeny. He claims that America is a "Reformed shaped" and even a "Reformed haunted" (Benne, 1995: 147, 179; cf. also Theron, 1999:324-337) nation and accuses mainstream Protestantism for reducing the classic Calvinistic themes of the sovereignty of God and the reign of Christ to "a more domesticated set of tunes that Protestant Christians themselves were to invent and realize without great pain and judgement" (p. 39). This tendency is also reflected in an obsession in certain circles with social ethics at the expense of interest in sound doctrine. Beizer contends that Calvin never tried to translate the kingdom of God into a programme of social ethics. ${ }^{10}$

Of course that does not mean that his theology has no social impact and implications. Not for nothing has Will Durant called the Institutes "one of the ten books that shook the world". ${ }^{11}$ Rightly or wrongly Calvinism has been acclaimed or blamed for many modern phenomena like capitalism, bureaucracy, liberal politics and apartheid. Michael Walzer in his wellknown work, The Revolution of the Saints - a study in the origins of radical politics, goes so far as to state that virtually all the modern world has been read into Calvinism (Walzer, 1965:300). We should, however, not forget the very appropriate phrase on the title page of the later

9 Also with regard to Calvin's theology it is important to distinguish between "letter" (form) and "spirit". Although the hands may be the hairy hands of Esau, the voice is the voice of Jacob. In other words: the letter may be Plato, but the spirit is Paul.

10 See Beizer (1993:117). For Calvin's ethics see the important pages on the imitation of Christ (Niesel, 1980:142 ff.)

11 On front page of the translation by Henry Beveridge of Institutes (see Calvin, 1962). 
editions of the Institutes which was also the prayer of Calvin on his death-bed, the words with which Heinrich Quistorp (1955) concludes his book on Calvin's doctrine of the last things: Quousque Domine? - How long. Lord?

Because of time restrictions I am not able to do justice to the many valuable and positive aspects of Prof. Van Wyk's paper. At the same time I must admit that I never thought the day would dawn that Stellenbosch would have to defend Calvin against Potchefstroom. For Stellenbosch this is a novel (and rather pleasant) experience. Since it concerns Calvin, I do not think it will be appropiate to call myself devil's advocate. Perhaps, due to our different contexts, Prof. Van Wyk sees his role more in line with the traditional devil's advocate in the Roman Catholic tradition, namely to prevent that a person is too easily proclaimed a saint. In Reformed theology that is probably an even more important and most meaningful, albeit a rather thankless, task. Therefore my sincere thanks to my colleague and friend, Amie van Wyk.

\section{Bibliography}

BAKKER, J.T. 1964. Eschatologische prediking bij Luther. Kampen : Kok.

BALKE, W. 1999. Some characteristics of Calvin's eschatology. Unpublished address at the Third Congress of the International Reformed Theological Institute, The Netherlands.

BEISZER, F. 1993. Hoffnung und Vollendung. Mohn : Gütersloh.

BENNE, R. 1995. The paradoxical vision. A public theology for the twenty-first century. Minneapolis : Fortress.

BERKOUWER, G.C. 1956. The triumph of grace in the theology of Karl Barth. Grand Rapids : Eerdmans.

BRUNNER, P. 1925. Vom Glauben bei Calvin. Tübingen : Mohr (Paul Siebeck).

CALVIN, J. 1962. Institutes. (Translated by Beveridge, H. Grand Rapids : Eerdmans.)

DEKKER, A. \& Puchinger, G. 1969. De Oude Barth. Kampen : Kok.

DEURLOO, K. A., VAN DEN BROM, L.J., Noordergraaf, H.J., De Jonge, H.J., et al. 1998. Verzoening of Koninkrijk. Over de prioriteit in de verkondiging. Nijkerk : Callenbach.

FORDE, G.O. 1997. On being a theologian of the cross. Reflections on Luther's Heidelberg Disputation, 1518. Grand Rapids, Mich : Eerdmans.

McGRATH, A. E. 1985. Luther's theology of the cross. UK : Blackwell.

NIESEL, W. 1980 [1956]. Theology of Calvin. Grand Rapids : Baker Book House.

QUISTORP, H. 1955. Calvin's doctrine of the last things. London : Lutterworth.

RETIEF, G.J. 1984. Die verhouding tussen mortificatio en vivificatio in die leer van die heiliging by Johannes Calvyn. Stellenbosch : University of Stellenbosch. (US: Unpublished dissertation.)

THERON, P.F. 1999. Blooming or bleeding? The "South African dream" in the light of eschatological peace. Ned. Geref. Teologiese Tydskrif, XXXX:324-3337.

TORRANCE, T.F. 1956. Kingdom and church - a study in the theology of the Reformation. Edinburgh : Olive \& Boyd.

WALZER, M. 1965. The revolution of the saints. Cambridge Mass : Harvard University Library.

WENDEL, F. 1980. Calvin. 9th impression. London : Fontana Library. 
